\title{
Coastal Pre-service Chemistry Teachers' Ability to Design Maritime Context-based Learning
}

\author{
Ardi Widhia Sabekti ${ }^{1}$, Inelda Yulita ${ }^{2}$, Nina Adriani ${ }^{3}$ \\ \{sabekti.ardi@umrah.ac.id¹ , inelda_chem@umrah.ac.id ${ }^{2}$,nina.adriani@umrah.ac.id ${ }^{3}$ \} \\ Department of Chemistry Education, Faculty of Teacher Training and Education,
}

Raja Ali Haji Maritime University, Indonesia ${ }^{1,2,3}$

\begin{abstract}
The study examined the ability of coastal pre-service chemistry teachers (CPCT) in designing maritime context-based learning. A case study approach was used to conduct the analysis in the University of West Coast of Bintan Island, Indonesia. Learning designs prepared by $21 \mathrm{CPCT}$ in their $3^{\text {rd }}$ year were evaluated by a rubric categorized into three parts with eight criteria subdivisions. The study found that CPCT was halfway in providing a connection between maritime daily life contexts and chemistry concepts. Moreover, CPCT had difficulties generating questions based on the required context in enhancing a maritime-based project. This result indicated that a systematic program was necessary for improving CPCT ability in designing maritime context-based learning
\end{abstract}

Keywords: pre-service teacher, maritime, context-based.

\section{Introduction}

A Coastal pre-service chemistry teacher (CPTC) is required to integrate chemistry learning in relation to a maritime context. This integration aims to indirectly improve the quality of learning for students in the coastal area and appreciate the maritime region's potential. Consequently, applying the chemistry concept in learning will improve the students' intrinsic motivation [1], conceptual understanding [2] and reduce students' alternative concepts [2]. There is also a strong correlation between classroom learning and societal fields [3], and this is aimed at improving the students' knowledge since they are able to relate the acquired chemistry concept with real-life situations around the maritime region.

Some of the Context-based chemistry learning designs that have been used before include the context of sport [4], human health [5], gas [6], and car engines [7]. Unfortunately, there is little concern given to the explicit maritime contexts in the design of chemistry learning. There is also limited information from the literature review on the pre-service chemistry teachers' ability to integrate maritime context-based learning designs. Previously, studies have been conducted to measure the ability of prospective physics teachers to make context-based assessments [8]. Therefore, this study aims to investigate the ability of CPCT to design maritime context-based learning. 


\section{Methods}

A case study technique was used in assessing the ability of CPCT in designing maritime context-based learning. It was carried out in the University of West Coast of Bintan Island, with a population target of $21 \mathrm{CPCT}$ in $3^{\text {rd }}$ year who were assigned to create maritime context-based learning in four weeks. Designs prepared by CPCT were evaluated by a rubric adapted from Stolk et al. [9], consisting of eight Design Strategies. They were categorized as not adequate (NA), partially adequate (PA), and adequate (A). A descriptive method was used to analyze the data presented in frequencies and percentages, as shown in (Table 1).

\section{Results and Discussion}

Results on 21 coastal pre-service chemistry teachers' ability to prepare learning designs based on maritime contexts are illustrated in Table 1.

Table 1. The ability of coastal pre-service chemistry teachers to design learning with maritime context.

\begin{tabular}{lllll}
\hline \multirow{2}{*}{ Part of CBL } & Design Strategies & \multicolumn{2}{c}{ Frequency } \\
\cline { 2 - 4 } & & NA & PA & A \\
\hline Context-based & Provide for a connection with chemistry concepts & 1 & 11 & 9 \\
introduction & Connect to students' daily lives & 0 & 10 & 11 \\
& Generate numerous questions & 10 & 4 & 7 \\
& Select questions that are practically feasible & 21 & 0 & 0 \\
Chemistry & Start with an explanation of chemistry concepts & 8 & 6 & 7 \\
concepts & Zoom into more detailed chemistry explanations & 4 & 12 & 5 \\
Context-based & Have a strong connection with the previous chem. & 20 & 1 & 0 \\
inquiry projects & explanations & 19 & 2 & 0 \\
\hline Total Frequency & Projects should be practically feasible & 83 & 46 & 39 \\
$\%$ & & 49.40 & 27.38 & 23.22 \\
\hline
\end{tabular}

Based on the results from Table 1, most of the CPCT had applied the chemistry context as an introduction to their learning and had successfully related it to the students" daily life. However, some CPCT were using the principle of "what to know" in Context-Based Learning $(\mathrm{CBL})[10]$. This was identified from those CPCT who analyzed questions that arose from the students and were related to the context displayed at the beginning of learning. Therefore, developing feasible questions was critical in designing context-based learning projects.

The majority of the CPCT had given brief explanations of chemical concepts related to the context under evaluation. Most of the teachers used the group discussion method with the help of a worksheet and others sought deeper explanations from textbooks in elaborating the contextbased chemistry concepts. However, some designs didn't have a clear explanation in relation to the concept being explained.

The study results highlighted that majority of the CPCT had not developed a context-based inquiry project. Additionally, the few that had designed the project it was not based on an elaborate concept. Therefore, using context as an introduction at the beginning of learning and the development of an inquiry project was a new invention in designing CBL-based learning 
design [9]. Furthermore, the study found out that CPCT needed improvement in their ability to design maritime context-based learning. Several teachers' professional development strategies could be adapted, such as frameworks that entailed setting a context in class, performing a new teaching role, and teaching content [11]. Moreover, an additional project was designed, including teaching an educative context-based unit and designing an outline of a new contextbased unit [12], as illustrated in Table 2.

Table 2. The maritime context in learning design.

\begin{tabular}{|c|c|c|c|}
\hline No & Context & Content & Frequency \\
\hline 1 & Coastal iron corrosion & Electrochemistry & 5 \\
\hline 2 & $\begin{array}{l}\text { Extracts of coastal natural resources as acid- } \\
\text { base indicators }\end{array}$ & Acid base & 1 \\
\hline 3 & Preserving food with salt & Macromolecule & 1 \\
\hline 4 & "Asam Manis" for Cermai fruit & Acid base & 1 \\
\hline 5 & Mangrove charcoal burning & Hidrocarbon & 1 \\
\hline 6 & Microplastics in coastal waters & Polymer & 1 \\
\hline 7 & $\mathrm{Al}$ and $\mathrm{Cu}$ on the ship, $\mathrm{Mg}$ from the sea & Period 3-4 Element & 1 \\
\hline 8 & Sea purification with green mussels & Colloid & 1 \\
\hline 9 & Betel nut & Buffer & 1 \\
\hline 10 & Petroleum mining & Hidrocarbon & 1 \\
\hline 11 & Bauxite excavated water quality & Acid base & 1 \\
\hline 12 & Compounds in seawater & Introduction of Chemistry & 1 \\
\hline 13 & General context and not maritime focus & Introduction of Chemistry & 3 \\
\hline 14 & General context and not maritime focus & Coloid & 2 \\
\hline \multicolumn{3}{|c|}{ Total } & 21 \\
\hline
\end{tabular}

The study identified 12 maritime contexts in the learning design despite the fact that the context of corrosion on ships was more recognized and familiar. Several maritime contexts also had emerged that were unfamiliar, for instance, the use of green mussels for water purification. The study also found that social and society domain contexts were most preferred by CPCT [10]. Consequently, this domain was important, especially in schools that aimed at preparing students to be responsible citizens by appreciating chemistry and its contribution to society. Finally, CPCT was able to make a connection between context and content, which was referred to as "fluid transitions" [3].

\section{Conclusion}

This study concluded that CPCT was halfway in terms of providing a connection between maritime daily life contexts with chemistry concepts. The CPCT experienced challenges in generating questions, especially in the introduced context. In addition, they had difficulties designing a context-based inquiry project from selected queries because they were not familiar. Furthermore, the study recommended a systematic program to help improve CPCT ability in designing maritime context-based learning. 
Acknowledgments. My gratitude goes to LP3M Raja Ali Haji Maritime University for the financial support and for ensuring the study was a success.

\section{References}

[1] Vaino, K., Holbrook, J., \& Rannikmae M.: Stimulating students' intrinsic motivation for learning chemistry through the use of context-based learning modules. Chemistry Education Research and Practice.Vol. 13, pp. 410-419 (2012)

[2] Baydere, F. K.: Effects of a context-based approach with prediction-observation-explanation on conceptual understanding of the states of matter, heat and temperature. Chemistry Education Research and Practice. Vol. 22, pp. 640-652 (2021)

[3] Bellocchi, A., King, D.T., \& Ritchie, S.M.: Context-based assessment: Creating opportunities for resonance between classroom fields and societal fields. International Journal of Science Education. Vol. 38, pp. 1304-1342 (2016)

[4] Potter, N.M. \& Overton, T.L.: Chemistry in sport: context-based e-learning in chemistry. Chemistry Education Research and Practice. Vol. 7, pp. 195-202 (2006)

[5] Amstrong, D. \& Poe, J.C.: The science of human health: a context-based chemistry course for nonscience majors incorporating systems thinking. Journal of Chemical Education. Vol. 97, pp. 3957-3965 (2020)

[6] Pavlin, J., Glazar, S.A., Slapnicar, M., \& Devetak, I.: The impact of students' educational background, interest in learning, formal reasoning and visualisation abilities on gas context-based exercises achievements with submicro-animations. Chemistry Education Research and Practice. Vol. 20, pp. 633-649 (2019)

[7] Cigdemoglu, C., \& Geban, O.: Improving students' chemical literacy levels on thermochemical and thermodynamics concepts through a context-based approach. Chemistry Education Research and Practice. Vol. 16, pp. 302-317 (2015)

[8] Ültay, E.: Examination of context-based problem-solving abilities of pre-service physics teachers. Journal of Baltic Science Education. Vol. 16, pp. 113-122 (2017)

[9] Stolk, M.J., Bulte, A., Jong O., Pilot, A.: Evaluating a professional development framework to empower chemistry teachers to design context-based education. International Journal of Science Education. Vol. 34, pp. 1487-1508 (2012)

[10] Jong, O.: Context-based chemical education:how to improve it?. Chemical Education International. Vol. 8, pp. 1-7 (2008)

[11] Dolfing, R., Prins, G.T., Bulte, A.M.W., Pilot, A., \& Vermunt, J.D.: Strategies to support teachers' professional development regarding sense-making in context-based science curricula. Science Education. Vol. 105, pp. 127-165 (2020)

[12] Stolk, M.J., Jong, O., Bulte, A.M.W. \& Pilot, A.: Exploring a framework for professional development in curriculum innovation: empowering teachers for designing context-based chemistry education. Research in Science Education. Vol. 41, pp. 369-388 (2011) 